\title{
Therapeutic Effect of Goat Milk Yogurt on Tumor Necrosis Factor Alpha (TNF- $\alpha$ ) Expression and Histopathology Changes of Aorta in Hypercholesterolemic Rat (Rattus norvegicus)
}

\author{
Chanif Mahdi*1, Masdiana C Padaga ${ }^{2}$ and Andhika R Pangetika ${ }^{2}$ \\ ${ }^{1}$ Department of Chemistry, Indonesia \\ ${ }^{2}$ Program Study of Veterinary Medicine, Indonesia
}

*Corresponding author: Chanif Mahdi, Department of Chemistry, Faculty of Mathematics and Natural Sciences, University of Brawijaya, Indonesia

\section{ARTICLE INFO \\ Received: 㗀January 28, 2019 \\ Published: 㗀 February 07, 2019}

Citation: Chanif Mahdi, Masdiana C Padaga, Andhika R Pangetika. Therapeutic Effect of Goat Milk Yogurt on Tumor Necrosis Factor Alpha (TNF- $\alpha)$ Expression and Histopathology Changes of Aorta in Hypercholesterolemic Rat (Rattus norvegicus). Biomed J Sci \& Tech Res 14(2)-2019. BJSTR. MS.ID.002522.

Keywords: Hypercholesterolemia; Goat Milk Yogurt; TNF- $\alpha$; Histopathology Aorta

\section{ABSTRACT}

Hypercholesterolemia is a risk factor for cardiovascular disease which causes the formation of oxidized LDL and triggers an inflammatory reaction, characterized by the release of cytokines TNF- $\alpha$ in the aorta. Goat milk yogurt containing lactic acid bacteria (LAB), bioactive peptides and antioxidants be an alternative therapy of hypercholesterolemia to reduce blood cholesterol levels. The purpose of this study was to determine the effect of goat milk yogurt therapy for hypercholesterolemia in terms of the expression of TNF- $\alpha$ and histopathological picture of the aorta. This study used 20 male rats Rattus norvegicus, Wistar strain were divided into 5 groups: control group (A), hypercholesterolemia group (B), hypercholesterolemia group and therapeutic dose of $300 \mathrm{mg} / \mathrm{kg}(\mathrm{C})$, hypercholesterolemia group and therapeutic dose of $600 \mathrm{mg} / \mathrm{kg}$ (D), as well as hypercholesterolemia and therapeutic dose group of $900 \mathrm{mg} / \mathrm{kg}$ (E). Rat model of hypercholesterolemia got hypercholesterolemia diet for 14 days and goat milk yogurt therapy for 28 days.

The results showed highly significant differences for each treatment group ( $p<0.01)$, which contained an average decrease in the expression of TNF- $\alpha$ by $61.14 \%$ (C); $37.54 \%$ (D); and $17.89 \%$ (E). Besides picture aortic histopathology showed that there was no improvement of endothelial desquamation, reduced lipid accumulation and infiltration of inflammatory cells in the aorta. The conclusion from this research that therapy goat milk yogurt can decrease the expression of TNF- $\alpha$ and improve picture rat aortic histopathology hypercholesterolemia models, with the most effective dose is a dose of $900 \mathrm{mg} / \mathrm{kg}$.

\section{Introduction}

Cardiovascular disease is one cause of death in the world with a mortality rate reaching 17.3 million people in 2008 and is epected to reach 23.6 million people by 2030 [1]. Hypercholesterolemia be the highest risk factor of cardiovascular disease that is characterized by total blood cholesterol levels above normal [2]. Normal cholesterol levels in humans $120-140 \mathrm{mg} / \mathrm{dl}$ and the pet animal such as a dog 92- $324 \mathrm{mg} / \mathrm{dl}$ [3]. The prevalence of hypercholesterolemia of 32.8\% from 192 dogs of Miniature Schnauzers in United States [4].
In both humans and animals, hypercholesterolemia often caused by a diet high in fat and cholesterol such as meat, offal, and brain. Low Density Lipoprotein (LDL) is a lipoprotein that play a role in the transport of cholesterol from the liver and peripheral tissues through the blood vessels. Consumption of foods high in cholesterol have the potential to raise blood cholesterol levels, especially LDL Krummel. LDL is reactive and easily oxidized into oxidized LDL (oxLDL). Ox-LDL can lead to endothelial dysfunction, loss of elasticity 
of blood vessels and the formation of plaque on the walls of the blood vessels [5].

Aortic blood vessels can be damaged due to the accumulation of LDL in the circulation, which in turn can activate immune pathway $\mathrm{NF}-\mathrm{\kappa B}$ and stimulates the release of proinflammatory cytokines Tumor Necrosis Factor Alpha (TNF- $\alpha$ ). Aortic damage is increasing as a result of TNF- $\alpha$ terekspresinya followed by the deposition of lipids in the aorta [6]. Hypercholesterolemia treatment using medicines from the class of statins. Various studies support the scientific evidence these drugs are effective for lowering blood cholesterol levels, but also cause various side effects such as the onset of anxiety and can affect liver function [7]. Consumption of probiotic products is a safe way to lower cholesterol levels. Yogurt is a probiotic food produced from milk through fermentation with the growth of lactic acid bacteria (LAB) [8]. Raw materials that can be used in the manufacture of such milk yogurt goat. Goat milk has advantages over cow's milk as composed of medium chain triglycerides (MCT) so accelerate the process of metabolism [9]. Goat milk proteins largely is similar to cow's milk, -s1-kaseinnya which is the trigger allergies, lower than cow's milk [10]. $\nabla$ but the content of Goat's milk yogurt supposedly can lower high cholesterol levels in the blood.

\section{Materials and Methods}

\section{Equipment and Materials}

Equipment used in this research is experimental animals maintenance tubs, bottles of drinking mice, rats feed container, stomach probes, thermometers, a set of tools surgical, petri dish, pipette measure, erlemenyer, measuring cup, flask, glass beaker, glass objects, cover glass, reagent bottle, microtube, Bunsen burners, lighters, pH meter (Eutech pH CYBERSCAN 310), pH indicators, analytical balance (Precisa 3000 D), O'hauss balance sheets, pots, stoves, rubber bulb, syringe, spatula, aluminum foil, auto micropipette, engine freeze dry (Christ Beta 1-8k), microtome cut frozen, tool centrifuge (Sorvall Biofuge Primo R Centrifuge, Sorvall Legend Micro 17), incubator (Memmert), vortex (Guo-Huq), a light microscope (Olympus BX51), autoclave and refrigerator. Materials used in the study were male rats (Rattus norvegicus) male Wistar strain obtained from UPHP Gajah Mada University by the age of 10-12 weeks and body weight 150-200 which has been approved by the ethics worthy UB's Research Ethical Commission No: KEP-217-UB, feed, goat milk is obtained from the Center for Training Ranch (BBPP) Stone, starter yoghurtmet (Lyo-San Inc: 500 Aeroparc, CP 598, Lachute, Qc, Canada, J8H 4G4) containing Lactobacillus bulgaricus, Lactobacillus aci- dophillus, and Streptococcus thermophillus) with a concentration of $109 \mathrm{CFU}$ / ml, cholic acid (Sigma, Catalog No: M5M5306), quail egg yolk, pork oil, dis the biological 0.9\%, PFA, alcohol-rise 70\%, 80\%, 90\%, absolute alcohol, xylol solution, H2O2, TNF- $\alpha$ antibody, SA-HRP, liquid paraffin (histoplats), histology hematoxilin- dye eosin (HE), balsam Canada and Entellan.

\section{Method}

\section{Preparation Animals}

Experimental animals were divided into five treatment groups, each consisting of four rats: control group (A), hypercholesterolemia group (B), hypercholesterolemia treated with a dose of $300 \mathrm{mg} / \mathrm{kg}$ BB (C), hypercholesterolemia treated with doses of $600 \mathrm{mg} / \mathrm{kg}$ (D), and hypercholesterolemia treated with a dose of $900 \mathrm{mg} / \mathrm{kg}$ (E). Diet manufacture hypercholesterolemia (hypercholesterolmia diet preparation) Diet feed hypercholesterolemia according to [11] consists of a mixture of lard $10 \%$, poached quail egg yolk and sour $5 \%$ cholic $0.1 \%$. The materials are added to $2 \mathrm{ml}$ of distilled water. Diet hypercholesterolemia granted for 14 days through a stomach sonde tilled water, PBS biological $\mathrm{NaCl}$ fisiologis $0.9 \%$, PFA, alcoholrise $70 \%, 80 \%, 90 \%$, absolute alcohol, xylol solution, H2O2, TNF- $\alpha$ antibody, SA-HRP, liquid paraffin (histoplats), histology hematoxilin- dye eosin (HE), balsam Canada and Entellan.

\section{Manufacture Starter}

$50 \mathrm{ml}$ goat milk is pasteurized for 5 minutes with the temperature 720C. Goat milk is cooled until it reaches $450 \mathrm{oC}$. Inoculation with starter yoghurt met powder with bacterial content of $0.25 \mathrm{~g}$ to $50 \mathrm{ml}$ of milk and do homogenization. Results inoculation starter incubated for at $45 \mathrm{oC}$ for 4 hours, until a starter in the $\mathrm{pH}$ range of 4.4 to 4.5 and kept in a refrigerator.

\section{Goat Milk Yogurt Manufacture (Yoghurt preparation)}

$500 \mathrm{ml}$ goat milk pasteurized at $72^{\circ} \mathrm{C}$ for 3 minutes. Goat milk is cooled until it reaches $450 \mathrm{c}$. Liquid starter inoculation 3\%, homogenized and incubated at $45 \mathrm{oC}$ for 4-8 hours to obtain a pH of 4.5-5 [12]. Goat milk yogurt made into freeze dry and stored at 4-50C.

\section{Therapeutic Administration of Goat Milk Yogurt}

Goat milk yogurt therapy is given orally by stomach sonde each tail mice in group C, D and E with mixed $1.5 \mathrm{ml}$ of distilled water. Therapy is given for 28 days after induction of hypercholesterolemia diet.

\section{Aorta Preparation}

The aorta is taken, namely the abdominal aorta. Rat dieuthanasi through dislocation of the neck, then performed abdominal surgery. Aortic tissue was taken and washed using a physiological $\mathrm{NaCl}$ 0.9\%. Network aorta put in paraformaldehyde (PFA) $4 \%$ for making preparations for histopathological examination and TNF- $\alpha$ expression. Observations expression of TNF- $\alpha$ is done through immunohistochemical staining methods. The specifications of the primary antibodies and secondary antibodies used are antirat TNF- $\alpha$ and biotin labeled goat anti-rat. Results observed using Olympus BX51 light microscope with a magnification of 400x. Aortic tissue expressing TNF- $\alpha$ appear brown that indicates an inflammatory reaction. TNF- $\alpha$ expression was visualized with Axio Vision software to calculate the percentage of the area. 


\section{Mixture with Eosin Staining Hematoxylin-}

Aortic tissue preparations included in xylol I, xylol II, and alcohol-rise (100\%, 90\%, 80\% and 70\%) and distilled water (Each 5minutes). Preparations were washed with PBS pH 7.4 (3x5min). Preparation Major stained with hematoxylin (5 minutes) and washed with distilled water (3x5menit). Wind dried preparations, mounting [13].

\section{Mixture Manufacture Histopathology}

The process of making preparations histopathological include: fixation, dehydration, purification (clearing), infiltration and embedding, manufacture blocks (blocking), cutting (sectioning), and the attachment of the glass object Joseph. Histopathological observations aorta preparations under Olympus BX51 light microscope magnification $400 \mathrm{x}-1000 \mathrm{x}$ done to look for changes in aortic tissue such as endothelial damage and damage to the tunica media in the form of descriptive qualitative lipid deposition.

\section{Data Analysis}

Data obtained from the measurement results of TNF- $\alpha$ expression in the aorta were analyzed with SPSS 16 software for Windows to perform variance analysis test (ANOVA) followed by Tukey test $\alpha=1 \%$, while the histopathological changes were analyzed qualitatively aorta to view and compare Histopathological picture aorta of each group.

\section{Results and Discussion}

Histopathology picture aorta in rats (Rattus norvegicus) Model Hypercholesterolemia treated Goat Milk Yogurt Histopathologic features aorta treated rat model of hypercholesterolemia goat milk yogurt can be observed in Figure 1. The control group (Figure 1A) shows the histology of the aorta in normal circumstances. Visible endothelial cells in the tunica intima flattened shape that arranged regularly attached to the basement membrane. Tunica media composed of elastin fibers and smooth muscle cells. This is in accordance with the opinion [14] which states the conditions of normal aorta seen from the tunica intima is composed of endothelial cells that form a flat (simple squamous epithelial cells) and a short polygonal subendothelial layer that consists of elastic fibers and collagen arranged longitudinally. Tunica media consists of smooth muscle cells and elastin fibers. Histopathological results of hypercholesterolemia group (Figure 1B), indicating tissue damage due to inflammation. The damage is characterized by endothelial desquamation (release of endothelial cells from the basal membrane), the tunica media are lipid deposition and infiltration of inflammatory cells and the structure of elastin fibers which are not regular.

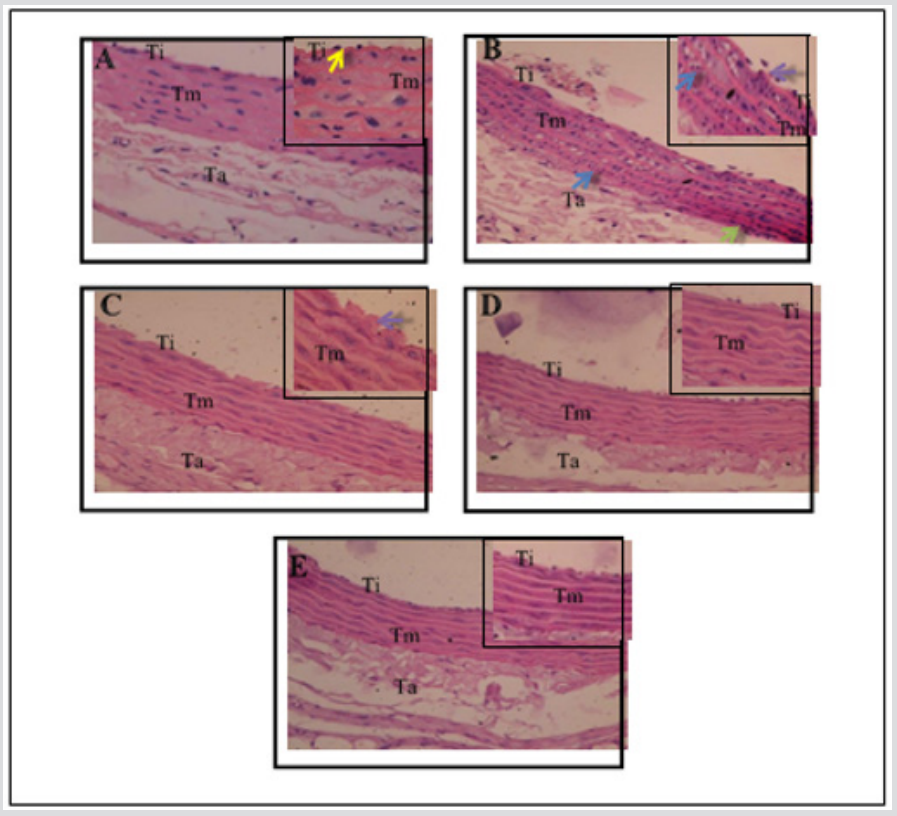

\section{Figure 1:}

a. Shows the histology of the aorta in normal circumstances.

b. Indicating tissue damage due to inflammation.

c. Shows the endothelial desquamation and structure elastin fibers irregular.

d. Showed improvement of endothelial cell layer are arranged neatly and elastin fibers structure was partially arranged regularly.

e. The highest dose in the treatment of aortic histopathology showed better picture than the dose of $300 \mathrm{mg} / \mathrm{kg}$ and 600 $\mathrm{mg} / \mathrm{kg}$, in the form of an intact endothelial layer and the structure of elastin fibers are arranged regularly. 
Endothelial desquamation occurs due to the accumulation of LDL in the circulation so that LDL accumulate and stick to the endothelium. The longer this condition can lead to increased endothelial permeability, which will further LDL into the inside intima through inter cell gap. High LDL will be reactive and oxidized by free radicals to form oxidized LDL (ox-LDL). Oxidation of LDL lead to adhesion molecules such as VCAM-1 will attract circulating monocytes toward the inflamed part. Monocytes then differentiate into macrophages. which will fagocyt LDL-ox. The number of macrophages describe the infiltration of inflammatory cells in the tunica media. Figure 1. Overview Histopathology Aorta in Rat Model Hypercholesterolemia (400x). Insert 1000x. Description: (A) control; (B) hypercholesterolemia; (C) goat milk yogurt therapeutic dose of $300 \mathrm{mg} / \mathrm{kg}$; (D) hypercholesterolemia treated goat milk yogurt dose of $600 \mathrm{mg} / \mathrm{kg}$; (E) hypercholesterolemia treated goat milk yogurt dose of $900 \mathrm{mg} / \mathrm{kg}$. Ti: The tunica intima; Tm: tunica media; Ta: tunica Adventisia: all groups (Figure 2). Group A (control) the expression of TNF- $\alpha$ has the least (Figure 2A), when compared with the other four groups. Brown areas most commonly found in group B (Figure 2B) compared with the other groups.

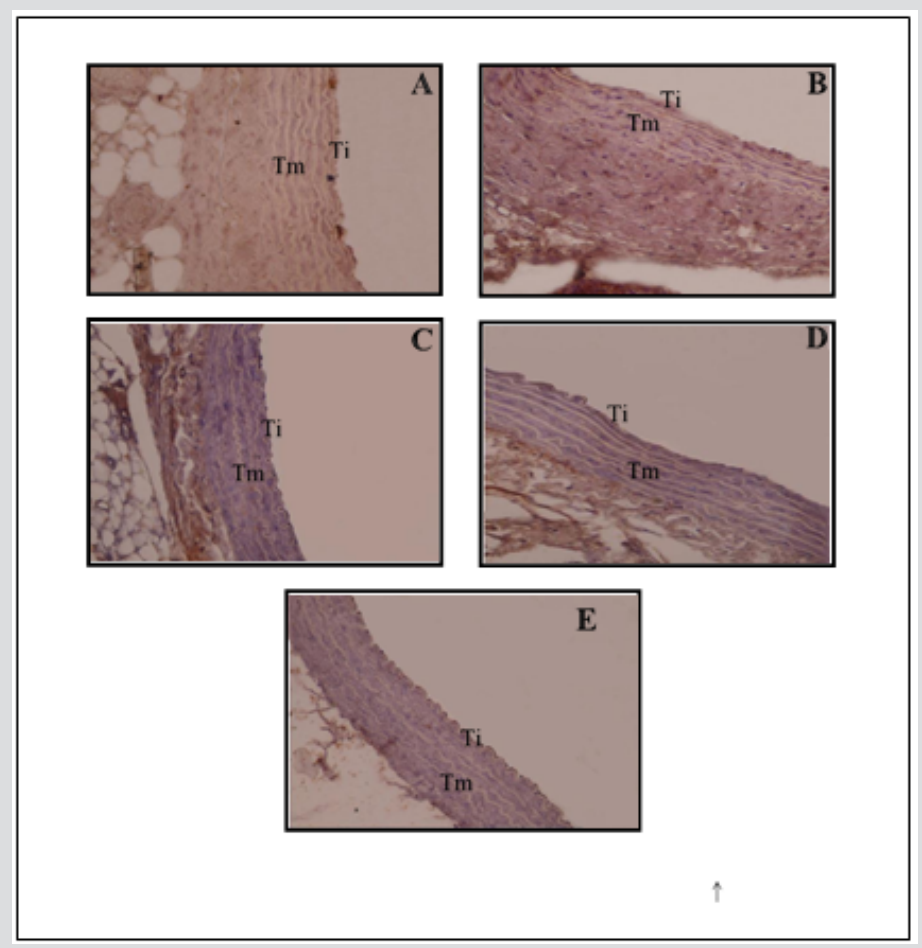

Figure 2: Expression of Tumor Necrosis Factor (TNF-a) in the Rat Aorta Model Hypercholesterolemia (400x). Ti: The tunica intima, Tm: tunica media, Ta: tunica adventitia. Signs black arrows (): the expression of TNF-a.

Expression of TNF- $\alpha$ therapy group declined indicated by the arrow is reduced. group therapy dose of $300 \mathrm{mg} / \mathrm{kg}$ (Figure 2C), $600 \mathrm{mg} / \mathrm{kg}$ BW (Figure 2D) and $900 \mathrm{mg} / \mathrm{kg}$ (Figure 2E) each show a brown area is less than the group hypercholesterolemia. This is supported by the results of visualization using Axio software Vission and obtained in units of percentage area (Table 1). This is in accordance with the opinion [14] which states the conditions of normal aorta seen from the tunica intima is composed of endothelial cells that form a flat (simple squamous epithelial cells) and a short polygonal subendothelial layer that consists of elastic fibers and collagen arranged longitudinally. Tunica media consists of smooth muscle cells and elastin fibers. Histopathological results of hypercholesterolemia group (Figure 1B), indicating tissue damage due to inflammation. The damage is characterized by endothelial desquamation (release of endothelial cells from the basal membrane), the tunica media are lipid deposition and infiltration of inflammatory cells and the structure of elastin fibers which are not regular. Endothelial desquamation occurs due to the accumulation of LDL in the circulation so that LDL accumulate and stick to the endothelium.

Table 1: Expression Tumor Necrosis Factor-a (TNF-a) of Aorta of hyper cholesterolamic rats' model.

\begin{tabular}{|c|c|c|}
\hline Treatment group & $\begin{array}{c}\text { Average of Expression } \\
\text { of TNF- } \boldsymbol{\alpha} \pm \text { SD }\end{array}$ & $\begin{array}{c}\text { Expression TNF- } \boldsymbol{\alpha} \\
\text { (\%) }\end{array}$ \\
\hline Control (A) & $1.14 \pm 0.65^{\mathrm{a}}$ & 10.0 \\
\hline $\begin{array}{c}\text { Hyper cholesrolamic } \\
\text { (B) }\end{array}$ & $11.40 \pm 0.99^{\mathrm{a}}$ & 100.0 \\
\hline $\begin{array}{c}\text { Hyper cholesterolamic } \\
\text { and therapy } 300 \mathrm{mg}\end{array}$ & $6.97 \pm 0.28^{\mathrm{c}}$ & 61.14 \\
\hline $\begin{array}{c}\text { Hyper cholestrerolamic } \\
\text { and therapy 600 mg }\end{array}$ & $4.28 \pm 0.41^{\mathrm{d}}$ & 37.54 \\
\hline $\begin{array}{c}\text { Hyper cholesterolamic } \\
\text { and therapy } 900 \mathrm{mg}\end{array}$ & $2.04 \pm 0.63^{\mathrm{a}}$ & 17.8 \\
\hline
\end{tabular}

The longer this condition can lead to increased endothelial permeability, which will further LDL into the inside intima through inter cell gap. High LDL will be reactive and oxidized by free radicals 
to form oxidized LDL (ox-LDL). Oxidation of LDL lead to adhesion molecules such as VCAM-1 will attract circulating monocytes toward the inflamed part. Monocytes then differentiate into macrophages. which will fagocyt LDL-ox. The number of macrophages describe the infiltration of inflammatory cells in the tunica media. Histopathologic features improved aortic hypercholesterolemia after therapy is given goat's milk yogurt. Hypercholesterolemia group therapy with a dose of $300 \mathrm{mg} / \mathrm{kg}$ (Figure 1C) shows the endothelial desquamation and structure elastin fibers irregular, but lipid deposition and infiltration of inflammatory cells in the tunica media decreases. Hypercholesterolemia group therapy with a dose of $600 \mathrm{mg} / \mathrm{kg}$ (Figure 1D) showed improvement of endothelial cell layer are arranged neatly and elastin fibers structure was partially arranged regularly. Hypercholesterolemia group therapy with a dose of $900 \mathrm{mg} / \mathrm{kg}$ (Figure 1E) as the highest dose in the treatment of aortic histopathology showed better picture than the dose of 300 $\mathrm{mg} / \mathrm{kg}$ and $600 \mathrm{mg} / \mathrm{kg}$, in the form of an intact endothelial layer and the structure of elastin fibers are arranged regularly.

Endothelial desquamation not formed due to reduced accumulation of LDL in the circulation. Endothelial structure back to normal and attached to the basement membrane, will restore endothelial function becomes more permeable so as to prevent the increasing number of lipid and inflammatory cells into the tissue of the aorta. As for the damaged cells had improved through the process of cell regeneration. This condition indicates that the therapeutic dose of 900 goat milk yogurt containing lactic acid bacteria (LAB), antioxidants and bioactive peptides can reduce oxidized LDL and inflammatory cell infiltration and repair damaged cells in the aorta. The mechanism of reduction in blood cholesterol through the activity of BAL occurs through the assimilation of cholesterol and bile acids dekonjugasi. BAL strain as L. bulgaricus, L. acidophillus and S. aureus were able to secrete enzymes Bile Salt Hydrolase (BSH) were influential in disposal of cholesterol in the blood for excretion, thus the accumulation of LDL in reduced circulation. This is supported by research $[15,16]$ that the enzyme capable BSH catalyzes the hydrolysis of conjugated bile salts into amino acid residues (Glycine and taurine) and salt-free bile (bile acids).

Dekonjugasi mechanism of bile salts followed by process $7 \alpha$-dehydroxylation to transform salt terdekonjugasi bile into secondary bile salts. Only a small portion of salt Secondary bile which can be absorbed by intestinal mucosa back to the liver and mostly wasted with feces. The antioxidants in goat milk yogurt including in the form of vitamins such as vitamin $\mathrm{C}$ and vitamin E. Antioxidants play a role in controlling free radicals and inhibit LDL oxidation reactions. All of groups (Figure 2). Group A (control) the expression of TNF- $\alpha$ has the least (Figure 2A), when compared with the other four groups. Brown areas most commonly found in group B (Figure 2B) compared with the other groups. Expression of TNF- $\alpha$ therapy group declined indicated by the arrow is reduced. group therapy dose of $300 \mathrm{mg} / \mathrm{kg}$ (Figure 2C), $600 \mathrm{mg} / \mathrm{kg} \mathrm{BB}$ (Figure 2D) and $900 \mathrm{mg} / \mathrm{kg}$ (Figure 2E) each show a brown area is less than the group hypercholesterolemia. This is supported by the results of visualization using Axio software Vission and obtained in units of percentage area (Table 1). dose of $300 \mathrm{mg} / \mathrm{kg}$ (Figure 2C), $600 \mathrm{mg} / \mathrm{kg}$ BW (Figure 2D) and $900 \mathrm{mg} / \mathrm{kg}$ (Figure 2E) each show a brown area is less than the group hypercholesterolemia. This is supported by the results of visualization using Axio software Vission and obtained in units of percentage area (Table 1). Table 1 shows the goat milk yogurt therapy during the 28-day influence was very significant $(p<0.01)$ on the expression of TNF- $\alpha$ between treatment groups.

Expression of TNF- $\alpha$ in mice control group (A) has the lowest expression. This condition is due to cholesterol levels remained within normal limits so that free radicals produced by the body, can still be offset by endogenous antioxidants. In addition, physiologically expressed TNF- $\alpha$ in the defense mechanism in the immune system homeostasis. Expression of TNF- $\alpha$ in contrast to the control group of mice hypercholesterolemia group, where hypercholesterolemia diet can increase LDL oxidation and free radicals. Reactive Oxygen Species (ROS) will turn lane high Nuclear Factor Kappa Beta (NF- $\kappa \mathrm{B}$ ) in stimulating the release of TNF- $\alpha$. This is supported by $[17,18]$ that hypercholesterolemia diet or atherogenic diet increases fatty acid oxidation in mitochondria that increased ROS production. ROS activates the transcription factor NF- $\mathrm{BB}$ and initiate a cascade that leads to phosphorylation of serine I $\kappa \mathrm{B}$. This causes the release of NF- $\kappa \mathrm{B}$ binding translocate from the cytoplasm into the cell nucleus (nucleus) automatically. Activation of NF- $\kappa B$ induces transcription of genes that play a role in inflammation, including proinflammatory cytokines TNF- $\alpha$. Goat milk yogurt can decrease the expression of TNF- $\alpha$ treatment group mice. Expression of TNF- $\alpha$ therapy dose of $300 \mathrm{mg} / \mathrm{kg}(\mathrm{C})$, $600 \mathrm{mg} / \mathrm{kg}$ (D) and $900 \mathrm{mg} / \mathrm{kg}$ (E) each significantly different between the groups, as well as to groups of hypercholesterolemia (B). Expression of TNF- $\alpha$ in group B had a percentage of $100 \%$.

Expression of TNF- $\alpha$ group C significantly different with group B with a percentage of $61.14 \%$. Expression of TNF- $\alpha$ group D different very real with group B with a percentage of $37.54 \%$. Expression of TNF- $\alpha$ group E significantly different with group B with a percentage of $17.89 \%$, but not significantly different with group A. This indicates that a dose of $900 \mathrm{mg} / \mathrm{kg}$ able to reduce the expression of TNF- $\alpha$ approaching normal conditions. Goat milk yogurt dose $900 \mathrm{mg} / \mathrm{kg}$ with a content of BAL, bioactive peptides, and antioxidants has a higher biological activity compared to the doses of 300 and 600 , so that they can lower cholesterol levels and affect the expression of TNF- $\alpha$. Therapeutic dose of 900 showed the best results among treatment group. Bioactive peptides in yogurt could be expected to decrease oxidative stress and controlling the inflammatory response as a result of the radical free. One of the bioactive peptides in yogurt is lactoferrin. [19] states that lactoferrin binds free iron will so as not to bind to free radicals that can inhibit the production of ROS. Lactoferrin can also act as an anti-inflammatory by inhibiting the release of proinflammatory 
cytokines TNF- $\alpha$. While BAL in yogurt of Lactobacillus strains according to [20] can improve the immune system by activating cells that stimulate the immune response and produce antiinflammatory cytokines. The antioxidants in goat milk yogurt act as an immune pathway inhibitor NF- $\kappa$ B. These barriers lead decreased levels of TNF- $\alpha$ in the circulation. [21] suggested that NF- $\kappa B$ lane

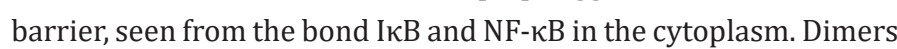
of NF- $\kappa B$ (p50 and p65) cannot be separated and subsequently did not occur translocation into the nucleus. This causes a decrease in the activity of the synthesis of several cytokines such as TNF- $\alpha$ proinflammatory be dropped. [22-24] adds that the expression of TNF- $\alpha$ barriers lead to decreased levels of TNF- $\alpha$, thereby preventing further tissue damage.

\section{Conclusion}

Giving goat milk yogurt with a dose of $300 \mathrm{mg} / \mathrm{kg}, 600 \mathrm{mg}$ / kg, and $900 \mathrm{mg} / \mathrm{kg}$ was able to lower the expression of TNF- $\alpha$ and improve the histopathological picture of rat aorta (Rattus norevgicus) model of hypercholesterolemia approaching negative control group (normal). Hypercholesterolemia therapeutic doses using goat's milk yogurt that shows the most effective result is a dose of $900 \mathrm{mg} / \mathrm{kg}$.

\section{Acknowledgment}

Thanks to Prof. Dr. Ir.Aulaniaam as head of Biochemistry Laboratory for the opportunity to study authors, Staff Veterinary Public Health Laboratory Animal Medicine Program, Staff Laboratory Staff Laboratory of Biochemistry and Animal Physiology of the Faculty of Mathematics and Natural Sciences, Polyclinic Staff Brawijaya University, Malang, Staff Laboratory RS. dr. Soetomo and Staff Laboratory of Pharmacognosy and Phytochemistry Faculty of Pharmacy, University of Airlangga, Surabaya.

\section{References}

1. (2011) WHO, Cardiovascular Disease (CVDs) (Online)

2. Bansal MP, Dan Sapna J (2009) Hypercholesterolemia Induced Oxidative is Stress Reduced in Rats with Diets Enriched with Supplement from Dunaliella saline algae. Am J Biomed Sci 1(3): 196-204.

3. Delaney CAJ (2008) Exotic Companion Medicine Handbook for Veterinarians. Zoological Education Network.

4. Xenoulis PG, Suchodolski JS, Levinski MD, Dan Steiner JM (2007) Investigation of Hypertriglyceridemia in HeaMiniature Schnauzers. Journal of Veterinary Internal Medicine 6: 1224-1230.

5. Esper RJ, Roberto AN, Jorge OV, Antonio P, José LC, et al. (2006) Endothelia Diabetology 5: 4.

6. Chen YH, Shing Jong L, Jaw Wen C, Hung Hai K, Dan Yuh Lien C (2002) Magnolol Attenuates VCAM-1 Expression in Vitro in TNF-a-treated Human Aortic Endothelial Cells and In Vivo in the Aorta of Cholestero Fed Rabbits. British Journal of Pharmacology 135(1): 37-47.
7. Fernandez G, Erica SS, Charles J, Dan Paul SP (2011) Statin Myopathy: A Common Dilemma Not Reflected in Clinical Trials. C level and Clinic Journal of Medicine 78(6): 393-403.

8. Shurtleff W, dan Aoyagi A (2007) History of Fermented Soymilk and Its Products. Soy Info Center Layafette California, USA.

9. Kompan D, Dan Komprej A (2012) The Effect of Fatty Acids in Goat Milk on Health. Milk Production: 1-26.

10. Ebringer L, Ferencik M, Dan Krajcovic J (2008) Beneficial Health Effects of Milk and Fermented Dairy Products. Folia Microbiologica 53(5): 378394.

11. Gani N, Momuat LI, Dan MM Pitoi (2013) Profil Lipida Plasma Tikus Wistar yang Hiperkolesterolemia pada Pemberian Gedi Merah (Abelmoschus manihot L). Jurnal Mipa Unsrat 2(1): 44-49.

12. Posecion NC, NL Crowe, AR Robinson, dan SK Asiedu (2005) The Development of Goat's Milk Yogurt. Journal of Science of Food and Agriculture 85: 1909-1913.

13. Ramos Vara JA (2005) Technical Aspects of Immunohistochemistry. Veterinary Pathology 42(4): 405-426.

14. Junquiera LC, Dan J Carneiro (2007) Basic Histology. The Mc Graw-Hill Companies.

15. Marie P, Edward RF, Dan Peter JH (2000) Consumption of Fermented and Nonfermented Dairy Products: Effect on Cholesterol Concentrations and Metabolism. Am J Clin Nutr 71: 674-81.

16. Baroutkoub A, Roushan ZM, Razmik B, Julayi H, Sohrabi Z, et al. (2010) Effects of Probiotic Yoghurt Consumption on the Serum Cholesterol Levels in Hypercholestromic Cases in Shiraz, Southern Iran. Scientific Research and Essays 5(16): 2206-2209.

17. Epstein FH (2003) Nuclear Factor Kappa Beta: A Pivotal Transcription Factor in Chronic Inflammatory Disease. NEJM 363(15): 1066-1071.

18. Lee H, Chun Yeon C, Chungwon C, Dan Youngsun S (2003) Attenuating Effect of Chlorella Supplementation on Oxidative Stress and NF-kB Activation in Peritoneal Macrophages and Liver of C57BL/6 Mice Fed on an Atherogenic Diet. Biosci Biotechnol Biochem 67(10): 2083-2090.

19. Guillen C, Mc Innes I, Kruger H, Dan J Brock (1998) Iron, Lactoferrin and Iron Regulatory Protein Activity in the Synovium; Relative Importance of Iron Loading and the Inflammatory Response. Ann Rheum Dis 57(5): 309-314.

20. Howarth GS, Dan Wang H (2013) Role of Endogenous Microbiota, Probiotics and Their Biological Products in Human Health. Nutrients 5: $58-81$.

21. Martin R, Hoeth M, Hofer Warbinek R, Dan Schmid J (2000) The Transcription Factor NF-kB and the Regulation of Vascular Cell Function. Arterioscler Throm Vasc Biol 10: 153-162.

22. Popa C, Netea MG, Van Riel PL CM, Van Der Meer JWM, Dan Stalenhoef AFH (2007) The Role of TNF- $\alpha$ in Chronic Inflammatory Conditions, Intermediary Metabolism and Cardiovascular Risk. Journal of Lipid Research 48: 751-759.

23. Berg A, Dan Scherer P (2005) Adipose Tissue, Inflammation, and Cardiovascular Disease. Journal of American Heart Association 21(12): 1873-1879.

24. Jusuf AA (2009) Histoteknik Dasar. Bagian Histologi FKUI, Jakarta, Indonesia. 


\section{ISSN: 2574-1241}

DOI: 10.26717.BJSTR.2019.14.002522

Chanif Mahdi. Biomed J Sci \& Tech Res

CC (i) This work is licensed under Creative

Submission Link: https://biomedres.us/submit-manuscript.php

$\begin{array}{ll}\text { BIOMEDICAL } & \text { Assets of Publishing with us } \\ \text { RESEARCHES } & \text { - Global archiving of articles } \\ \text { - Immediate, unrestricted online access } \\ \text { https://biomedres.us/ }\end{array}$

